\title{
Productivity of Grafted Tomato Grown in the Summer Season Under The New Valley Environmental Conditions
}

\section{Eman G. Ali ${ }^{1}$, M. F. Mohamed ${ }^{2}$, M. A. Farghali ${ }^{2}$ and M. S.S. Abdel-Rahman ${ }^{2}$}

${ }^{1}$ Faculty of Agriculture in the New Valley, Assiut University branch, EL-Kharga Oasis.

${ }^{2}$ Department of Vegetable Crops, Faculty of Agriculture Assiut University, Assiut

\section{Abstract:}

This study was carried out at the Experimental farm of the New Valley Agriculture Research Station (EL-Kharga Oasis), New Valley, Egypt, during summer season in 2012 and 2013. Four tomato cultivars ['Castle Rock' (CR), 'StrainB' (SB), 'Super Marmande' (SM) and 'Peto-86' (P86)] were used to determine whether grafting could improve high temperature tolerance. The experiment included 20 treatments (12 treatments were cross-grafts and 4 treatments were selfgrafts, in addition, to 4 intact plant treatments). Under the conditions of this study, intact plants of cvs 'SM' and 'P86' did not survive and their rootstock also neither supported their own scion (self-grafts) nor the alien scions of cvs 'CR' and 'SB' (cross-grafts). The remaining treatments showed that self-grafted plants were superior to their corresponding intact plants especially for early harvesting and total fruit yield. Cross-grafted plants surpassed their corresponding selfgrafted plants in all studied traits. Out of the current study, it is advisable to grow the cross-graft 'CR' / 'SB' or 'SB' / 'CR' for production of tomato during the stressful climatic conditions of summer season in the New Valley. The estimated vigor for total fruit yield in these two cross-grafts, respectively, over their corresponding intact plants averaged $148.9 \%$ and $136.2 \%$.

Keywords: crop improvement, environmental stress, grafting, heat tolerance, Lycopersicon esculentum Mill. 


\section{Introduction:}

Environmental stresses represent the most limiting conditions for horticultural productivity. Important factors among those are drought, salinity, high and low temperature, nutrition deficiency, light stress, and plant pathogens. One direction to reduce the adverse effect of the environmental stresses is to develop crop cultivars that are more resistant/tolerant to such stresses. This is carried out with tremendous efforts particularly with plant breeding. However, classical breeding is slow and time consuming but recent advances of practical selection tools like genetic markers would accelerate the process so far.

A special method of adapting plants to counteract environmental stresses is by grafting elite commercial cultivars onto selected rootstocks (Lee and Oda, 2003). Grafting is nowadays regarded as a rapid alternative tool to the relatively slow breeding methodology aimed at enhancing environmental-stress tolerance of fruit vegetables (Flores et al., 2010). In vegetable production, grafting is already used for more than 50 years ago in many parts of the world. Grafting is not associated with the input of agrochemicals to the crops and is, therefore, considered to be an environment-friendly operation of substantial and sustainable relevance to integrated and organic crop management systems (Rivard and Louws, 2008). The cultivated area of grafted Solanaceae and Cucurbitaceae has increased tremendously in recent years because the idea of grafting has been greatly expanded (Lee et al., 2010). Nowadays, grafting is used to reduce infections by soil-borne pathogens and to enhance the tolerance against various abiotic stresses. Among those are saline soils (Colla et al., 2010), soil-pH (alkalinity) stress, nutrient deficiency, and toxicity of heavy metals (Savvas et al., 2010). Other abiotic conditions for the application of rootstocks are thermal stress, drought and flooding, and persistent organic pollutants. The objective of the current investigation was to determine whether grafting could improve crop performance under high temperature and arid conditions in the New Valley.

\section{Materials and Methods:}

This study was carried out at the Experimental farm of the New Valley Agricultural Research Station (EL-Kharga Oasis), New Valley, Egypt, during the summer season in 2012 and 2013. Soil and irrigation water analyses and the minimum and maximum temperature at the experimental site during the growing seasons of the study are presented in Tables (1, 2 and 3), respectively. Four tomato cultivars namely, 'Castle Rock' (Castle Seed Co., USA), 'Strain-B' (Ferry-Morse Seed Co., USA), 'Super Marmande' (Abundance Co., France) and 'Peto-86 (Moon Star Co., Pakistan) were used. Seeds used in the whole course of this study were from the same seed lot.

The experiment included 20 treatments. Twelve treatments were crossgrafts and four treatments were self-grafts (positive control), in addition, to four intact plant treatments (positive control). Seeds were sown on the May 12 and 8 in 2012 and 2013, respectively. For preparations of scions and rootstocks, seeds were sown, separately, in 209 whole trays filled with peat moss. One seed of each cultivar was sown in each hole of the trays and then they were thoroughly irrigated. Grafting started when the second true leaf of the rootstock and the first true leaf of the scion were established. The grafting cut for rootstock was made in a downward direction and the scion was cut in an upward direction at an angle 
about $40^{\circ}$ to the perpendicular axis, and deep enough to allow the fusion of as many vascular bundles as possible. After the grafting is completed, especially designed clips are placed to fix the graft position. Grafted plants were kept under clear polyethylene plastic cover for about 5 days to heal and establish the joining surface. Partial shading was applied during the daytime to avoid excessive heat build-up. The grafting method used here is described in details by Lee and Oda (2003).

One seedling was transplanted in the field $30 \mathrm{~cm}$ apart on the northern side of ridges $1.2 \mathrm{~m}$ wide and $3 \mathrm{~m}$ long on June, 26 in 2012 and on June, 22 in 2013. Soil preparation and all cultural practices were done as recommended for production of tomato (Hassan, 2008). An experiment including the 20 treatments (factorial 4 x 4 treatments plus 4 intact plant treatments) was arrangement in randomized complete-blocks with three replicates.

Data were recorded for average number of days from transplanting to harvesting, fruit yield (ton/feddan), average fruit weight $(\mathrm{g})$, number of fruits per plant and fruit dry matter percent $(200 \mathrm{~g}$ of fruit flesh from several fruit parts was cut off, then fresh weight, and dried in a fan electric oven at $70^{\circ} \mathrm{C}$ until constant weight). All data were subjected to analysis of variance according to Gomez and Gomez (1984). Means were compared using the Least Significant Difference Test (LSD) at 0.05 probability level.

Table (1): Chemical analysis of irrigation water from the ground water at the agricultural Research Station in El- Kharga Oasis.

\begin{tabular}{|c|c|c|}
\hline Character & 2012 & 2013 \\
\hline $\mathrm{EC} \mathrm{dSm}^{-1}$ & 0.31 & 0.45 \\
\hline $\mathrm{pH}$ & 6.70 & 6.55 \\
\hline \multicolumn{3}{|l|}{ Soluble cations meq $1^{-1}$} \\
\hline $\mathrm{Ca}^{+2}$ & 0.72 & 1.02 \\
\hline $\mathrm{Mg}^{+2}$ & 0.69 & 1.11 \\
\hline $\mathrm{Na}^{+1}$ & 1.03 & 1.25 \\
\hline $\mathrm{K}^{+1}$ & 0.64 & 1.07 \\
\hline \multicolumn{3}{|l|}{ Soluble anions meq $\mathrm{l}^{-1}$} \\
\hline $\mathrm{CO}_{3}{ }^{-2}+\mathrm{HCO}_{3}^{-1}$ & 1.57 & 2.11 \\
\hline $\mathrm{Cl}^{-1}$ & 1.15 & 1.48 \\
\hline $\mathrm{SO}_{4}^{-2}$ & 0.34 & 0.86 \\
\hline SAR & 1.22 & 1.21 \\
\hline $\mathrm{Fe}(\mathrm{ppm})$ & 1.15 & 1.43 \\
\hline Mn (ppm) & 0.10 & 0.10 \\
\hline
\end{tabular}


Table (2): Mechanical and chemical soils analysis of the experimental site.

\begin{tabular}{|c|c|c|}
\hline Soil characteristics & Depth $(0-30 \mathrm{~cm})$ & Depth $(30-60 \mathrm{~cm})$ \\
\hline Sand $\%$ & 69.54 & 47 \\
\hline Silt\% & 11,46 & 39 \\
\hline Clay $\%$ & 19 & 14 \\
\hline Texture & Sandy clay loam & Sandy clay loam \\
\hline $\mathrm{CaCO}_{3} \%$ & 1.9 & 1.5 \\
\hline $\mathrm{EC}(1: 5$ extract $) \mathrm{dSm}^{-1}$ & 0.56 & 0.59 \\
\hline $\mathrm{pH}(1: 1$ suspension $)$ & 7.5 & 7.5 \\
\hline $\mathrm{Ca}+{ }^{2} \mathrm{Meq}(100 \mathrm{~g}$ soil/L) & 7.5 & 7.5 \\
\hline $\mathrm{Mg}+{ }^{2} \mathrm{Meq}(100 \mathrm{~g}$ soil/L) & 1.1 & 0.92 \\
\hline $\mathrm{Na}+\mathrm{Meq}(100 \mathrm{~g}$ soil/L) & 0.9 & 1.1 \\
\hline $\mathrm{K}+$ Meq(100gsoil/L) & 0.47 & 0.85 \\
\hline $\mathrm{HCO}_{3}$ & 0.6 & 0.6 \\
\hline $\mathrm{Cl}^{-}$ & 1.25 & 1.19 \\
\hline $\mathrm{SO}_{4}^{-2}$ & 1.19 & 1.28 \\
\hline
\end{tabular}

Table (3): Minimum and maximum temperature of EL-Kharga city (New Valley) during the growing seasons of the study.

\begin{tabular}{|l|c|c|c|c|}
\hline & \multicolumn{2}{r|}{ Season } & \multicolumn{2}{c|}{2013} \\
Month & \multicolumn{2}{c|}{2012} & Min & Max \\
\hline & Min & Max & 27.1 & 43 \\
\hline June & 24.7 & 43.7 & 22.9 & 38.8 \\
\hline July & 22.9 & 40.2 & 22.9 & 42 \\
\hline August & 25 & 41.1 & 24.7 & 39.2 \\
\hline September & 24.9 & 38.3 & 23.7 & 33 \\
\hline October & 22.5 & 35.5 & 17.3 & 28.5 \\
\hline November & 19.6 & 33.1 & 13.8 & \\
\hline
\end{tabular}

\section{Results and Discussion:}

The process of developing a productive grafted cultivar is attained through two main steps. The first is to identify a compatible rootstock that serves the intended objective. The second is to select the elite specific combination of scion and rootstock. Under the conditions of this study (Tables 1, 2 and 3), high temperature during the summer season seems to be the most stressful factor. Under this conditions, intact plants of cvs 'Super Marmande' and 'Peto-86' did not survive. Roots of these two cvs also neither support their own scion (self-grafts) nor alien scions of cvs 'Castle Rock and Strain-B' (cross-grafts). Thus ten treatment entries remained for testing in the course of this study. These ten treatments were: 1) three cross-grafts of cvs 'Castle Rock', Super Marmande' and 'Peto-86' scions on cv 'Strain-B' rootstock, 2) three cross-grafts of cvs 'Strain-B', Super Marmande' and 'Peto-86' scions on cv 'Castle Rock' rootstock, 3) two self- 
grafts for cvs 'Castle Rock' and 'Strain-B' and 4) two intact plant treatments for cvs 'Castle Rock' and 'Strain-B'.

Obviously, self-grafted plants of cv 'Strain-B' were superior to its intact plants regarding early harvesting (Fig. 1A and B), total fruit yield (Fig. 2A and B), number of fruits per plant (Fig. 3A and B) average fruit weight (Fig. 4 A and B) and fruit dry matter content (Fig. $5 \mathrm{~A}$ and B). The increases as percentage were 5.11, 54.27, 27.16, 20.63 and $12.40 \%$, respectively. 'Castle Rock' cv showed similar superiority but average fruit weight and fruit dry matter content did not appreciably change. The increases for early harvesting, total fruit yield and number of fruits per plant as percentage were $6.03,35.50$ and 31.26 , respectively. This demonstrates that tissue wounding and reunion process of the selfgrafting operation per se evoked a stimulation inducing crop vigor. This may be attributed to increased activity of antioxidant enzymes as observed by Rivero et $a l .$, (2003). Enhancing activity of antioxidant enzymes improve photosynthesis in tomato (He et al., 2009) and in eggplant (Liu et al., 2007). Cross-grafted scions of cv Strain-B' (Strain-B/'Castle Rock') and cv 'Castle Rock' ('Castle Rock'/ Strain-B), as compared to their corresponding self-grafted plants (Strain-B/ Strain-B and 'Castle Rock'/'Castle Rock'), manifested a significant increase in all studied traits (Fig. 1 C and D to $5 \mathrm{C}$ and D). The increases were 5.64 and 12.76 $\%$ for early harvesting 56.77 and $93.24 \%$ for total fruit yield 35.58 and $114.44 \%$ for number of fruits per plant 14.47 and $9.33 \%$ for average fruit weight and 9.56 and $15.32 \%$ for fruit dry matter content. Since cross-grafting includes tissue wounding and reunion process alike the self-grafting operation, then additional stimulation seems to be incorporated by specific compatibility factors. This may include specific root/shoot signals (Aloni, et al., 2010) including RNA transport. (Harada et al., 2010).

Scions of 'Peto-86' and 'Super Marmande' grafted on 'Strain-B' rootstock ('Peto-86'/ 'Strain-B' and 'Super Marmande'/'Strain-B') as compared to their grafting on 'Castle Rock' rootstock ('Peto-86'/'Castle Rock' and 'Super Marmande'/'Castle Rock') showed an increase in all traits (Fig. $1 \mathrm{E}$ and $\mathrm{F}$ to $3 \mathrm{E}$ and $\mathrm{F}$ and Fig. $5 \mathrm{E}$ and F) except for average fruit weight (Fig. $4 \mathrm{E}$ and F). The increases for early harvesting, total fruit yield and number of fruits per plant as percentage were 4.17 and 3.36, 64.87 and 22.21 and 103.82 and $51.99 \%$, respectively. Self-grafts were not available here due to their mortality. However, superiority of 'Peto-86' and 'Super Marmande' scions on 'Strain-B' rootstock indicates an existence of specific root/shoot compatibility factors. In an alignment, while cvs 'Castle Rock' on 'Strain-B' were closely similar in productivity, cross-grafted scions of cv 'Castle Rock' on Strain-B rootstock tended also to be superior (especially in earliness of harvesting, $15.3 \%$ and total fruit yield, $92.4 \%$ ) to crossgrafts of cv Strain-B' scion on rootstock of 'Castle Rock'. As far as the fruit size is concerned, it is shown here that in all cases rootstock of 'Castle Rock' evidently increased average fruit weight. Meanwhile, rootstock of 'Strain-B', although it produced fruits of less weight, they commercially still of acceptable size.

In their review concerning the grafting to improve crop performance, Schwarza, et al., (2010) mentioned that prediction of elite specific combination of scion and rootstock is still a matter of try and error due to the lack of potential 
selection aiding markers. Among the reported mechanisms for resistance/tolerance to heat-stress are reduction of root elongation and development of multiple mineral deficiencies ( $\mathrm{P}$ and $\mathrm{Fe}$ ) in roots and shoots, which both can increase ethylene production. Grafting tomato onto a heat tolerant rootstock (L. esculentum cv. RX-335) resulted in a decreased of hydrogen peroxide concentration indicating the lower oxidative stress (Rivero et al., 2003). It is worthwhile to mention that results presented here suggest that root genotype has an initial prominent role in the performance of tomato crop under the condition of the current study. This can be noticed in 'Peto-86' and 'Super Marmande' in which roots were not able to maintain scions of the 'Strain-B' and 'Castle Rock'. Further, scions of 'Peto-86' and 'Super Marmande' produced higher fruit crop when grafted on rootstock of cvs 'Strain-B' as compared to 'Castle Rock'. Cross-grafted scions of cv 'Castle Rock' on 'Strain-B' rootstock ('Castle Rock'/ Strain-B) tended also to be superior (especially in earliness of harvesting and total fruit yield) to crossgrafts of cv Strain-B' on rootstock of 'Castle Rock' (Strain-B/'Castle Rock'). However, observing the great variation in performance among scions of 'Castle Rock' 'Peto-86' and 'Super Marmande' when cross-grafted on 'Strain-B' rootstock as a relatively heat tolerant $\mathrm{cv}$ (Mohamed et al., 2002) implies for an important role for shoot genotype. As a guideline, crop improvement can be achieved for non heat-stress adapted tomato by grafting their scions on roots of genotypes possessing a heat tolerance. However, outstanding crop gain would be obtained from shoot/root exchange between heat adapted genotypes. Out of the current study, it is advisable to grow the cross-graft 'Castle Rock' / 'Strain-B' or 'Strain-B' / 'Castle Rock' for production of tomato during the stressful summer season in the New Valley. The estimated vigor for fruit yield for 'Castle Rock' / 'Strain-B' and 'Strain-B' / 'Castle Rock' over their corresponding intact plants averaged for $148.9 \%$ and $136.2 \%$, respectively. 
Self graft 2012

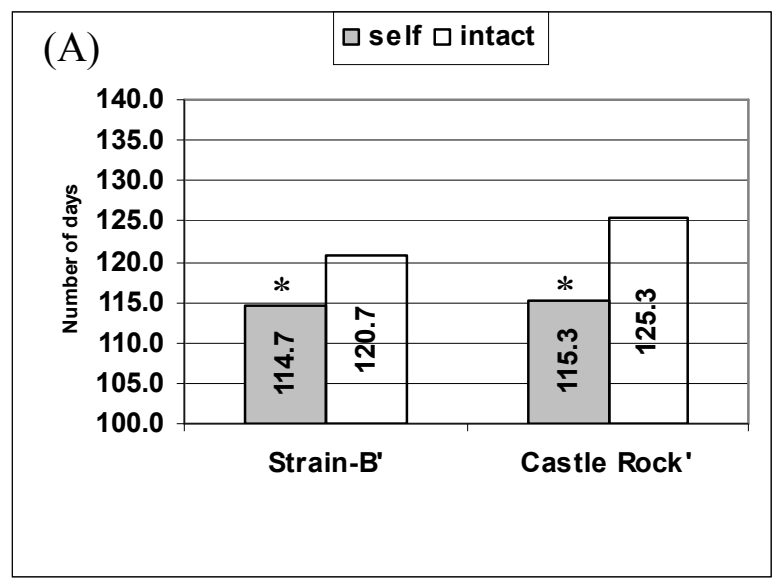

$\mathrm{LSD}_{0.05}: \mathrm{Cvs}=1.2$, Self-grafts $=1.2$ CvsXSelf-grafts $=1.7$
Self graft 2013

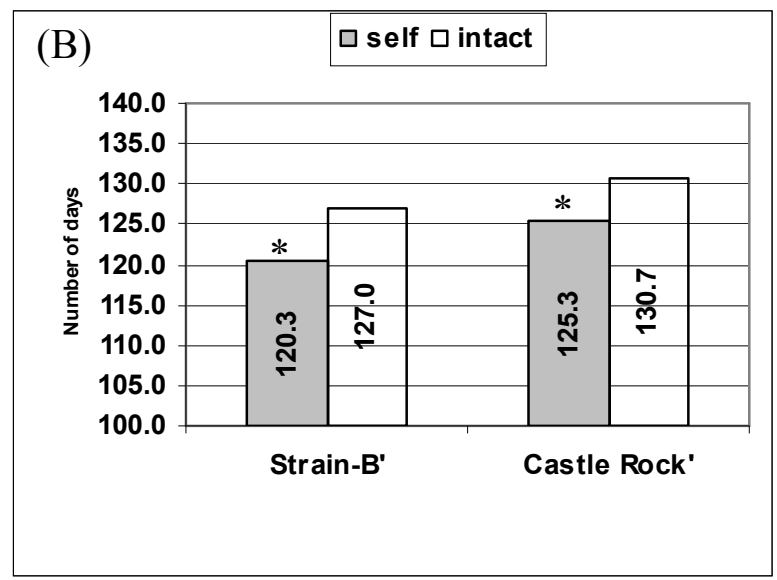

$\mathrm{LSD}_{0.05}:$ Cvs $=0.7$ Self-grafts $=0.7$ CvsXSelf-grafts $=0.9$ 2012
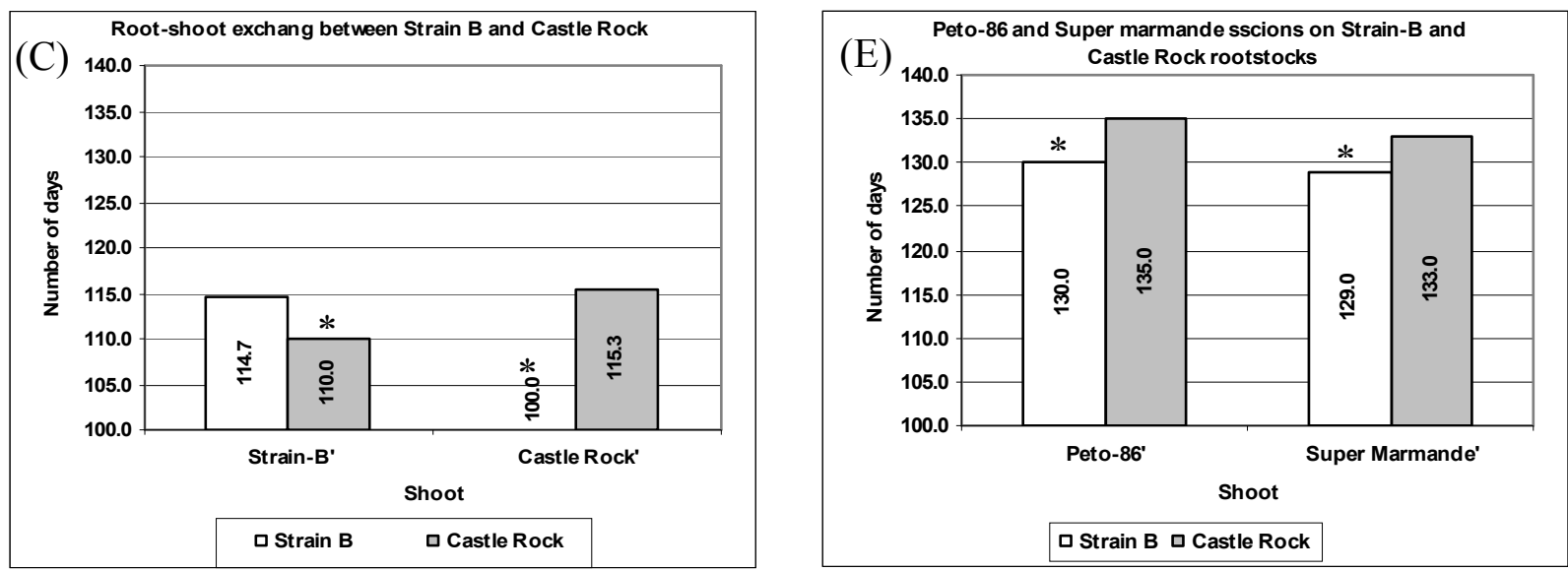

$\mathrm{LSD}_{0.05}:$ Root $=0.5$ Shoot $=0.7$ RootXShoot $=1.1$

Cross grafts 2013
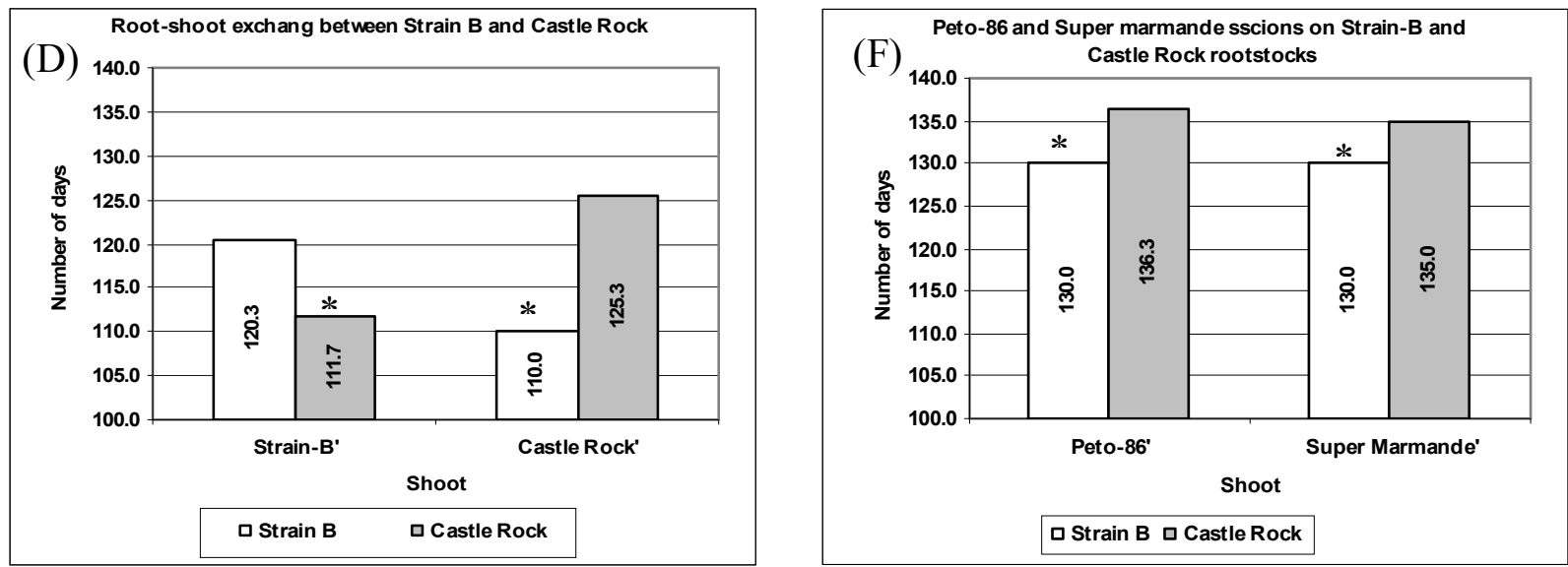

$\operatorname{LSD}_{0.05}:$ Root $=1.0$ Shoot $=1.5$ RootXShoot $=2.1$

Fig., (1): Average number of days to flowering in the summer season in 2012 and 2013 for self-grafts versus intact plants of tomato cultivars 'Strain-B' and 'Castle Rock' (A and B), cross-grafts resulted from root/shoot exchange between cv 'Strain-B' (SB) and cv 'Castle Rock' and cross-grafts of cv 'Peto-86' and 'Super Marmande' scions on rootstocks of cv 'Strain-B' and 'Castle Rock' . Stars denote significant difference between each two adjacent columns. 


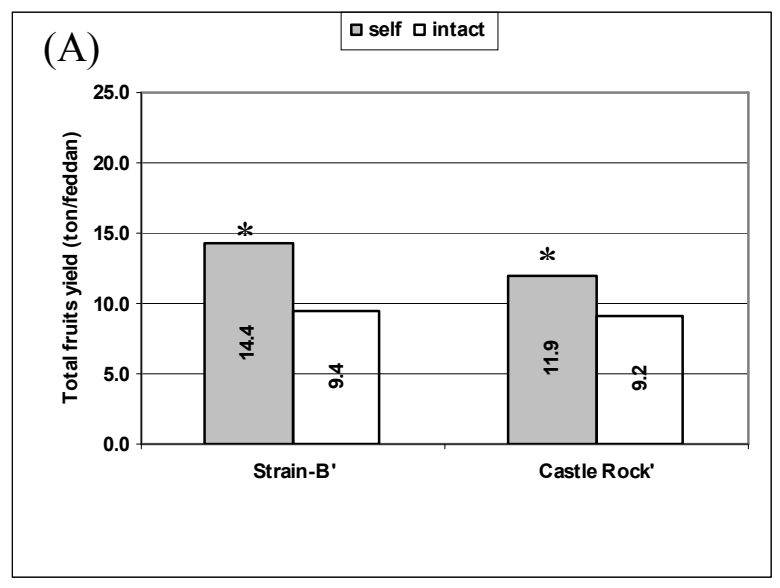

$\mathrm{LSD}_{0.05}:$ Cvs $=0.5$, Self-grafts $=0.5$ CvsXSelf-grafts $=0.7$

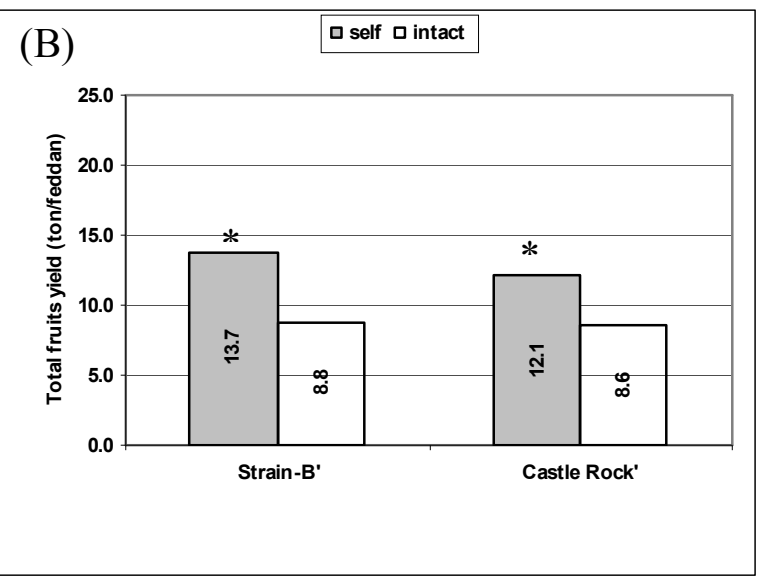

$\mathrm{LSD}_{0.05}:$ Cvs $=0.3$ Self-grafts $=0.3$ CvsXSelf-grafts $=0.5$

Cross grafts 2012
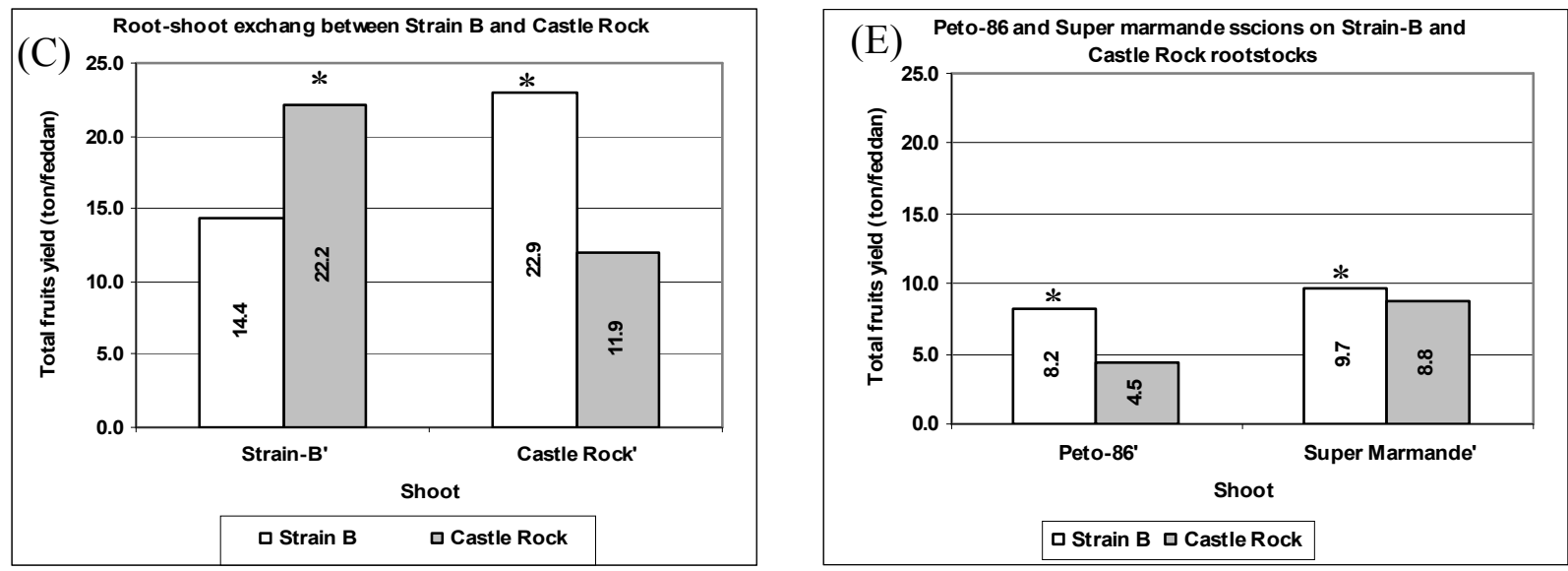

$\mathrm{LSD}_{0.05}:$ Root $=0.5$ Shoot $=0.6$ RootXShoot $=0.9$

Cross grafts 2013
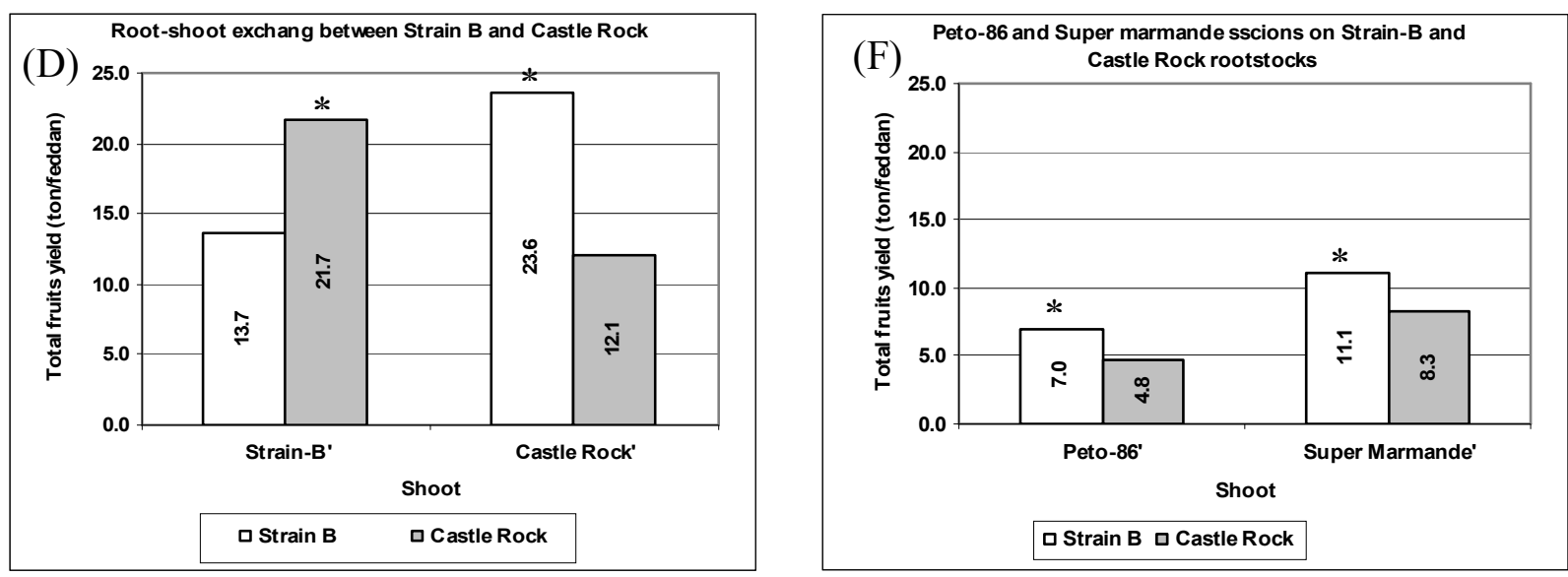

$\mathrm{LSD}_{0.05}:$ Root $=0.3$ Shoot $=0.4$ RootXShoot $=0.6$

Fig., (2): Average total fruit yield (ton/Feddan) produced in the summer season in 2012 and 2013 for self-grafts versus intact plants of tomato cultivars 'Strain-B' and 'Castle Rock' (A and B), cross-grafts resulted from root/shoot exchange between cv 'Strain-B' (SB) and cv 'Castle Rock' and cross-grafts of cv 'Peto-86' and 'Super Marmande' scions on rootstocks of cv 'Strain-B' and 'Castle Rock' . Stars denote significant difference between each two adjacent columns. 


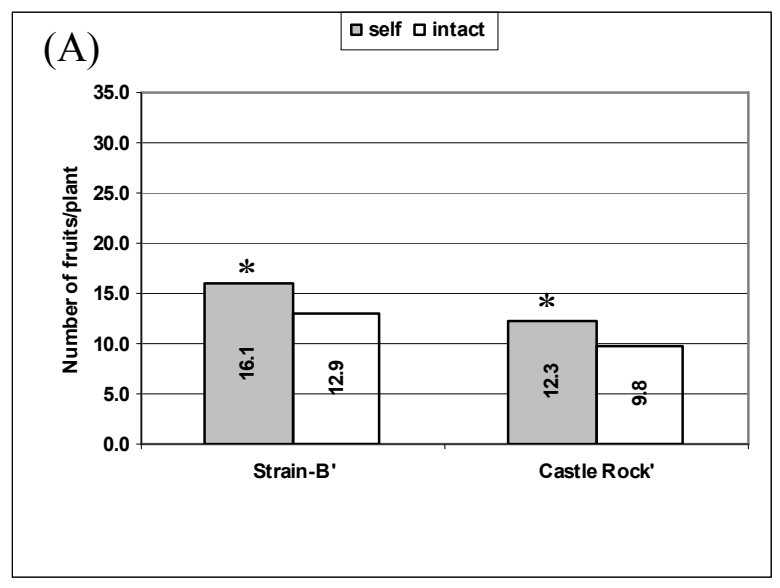

$\mathrm{LSD}_{0.05}: \mathrm{Cvs}=0.8$, Self-grafts $=0.8$ CvsXSelf-grafts $=1.1$

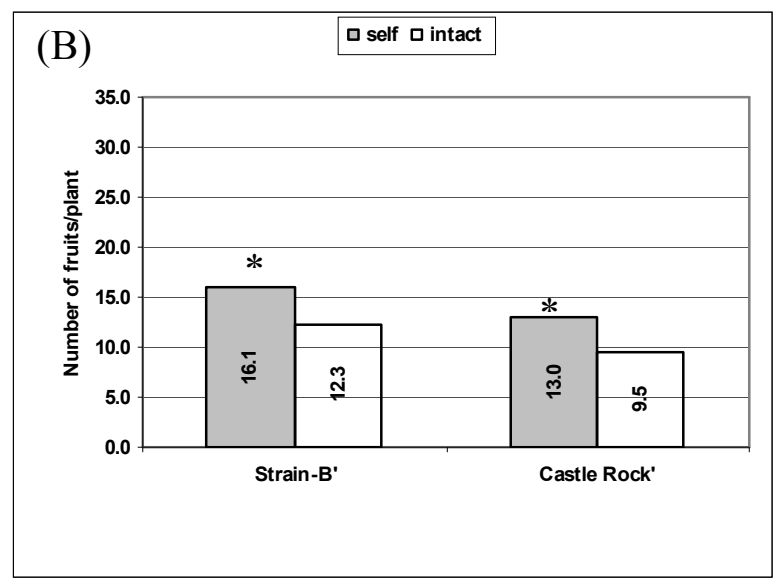

$\mathrm{LSD}_{0.05}:$ Cvs $=0.7$ Self-grafts $=0.7$ CvsXSelf-grafts $=1.0$ Cross grafts 2012
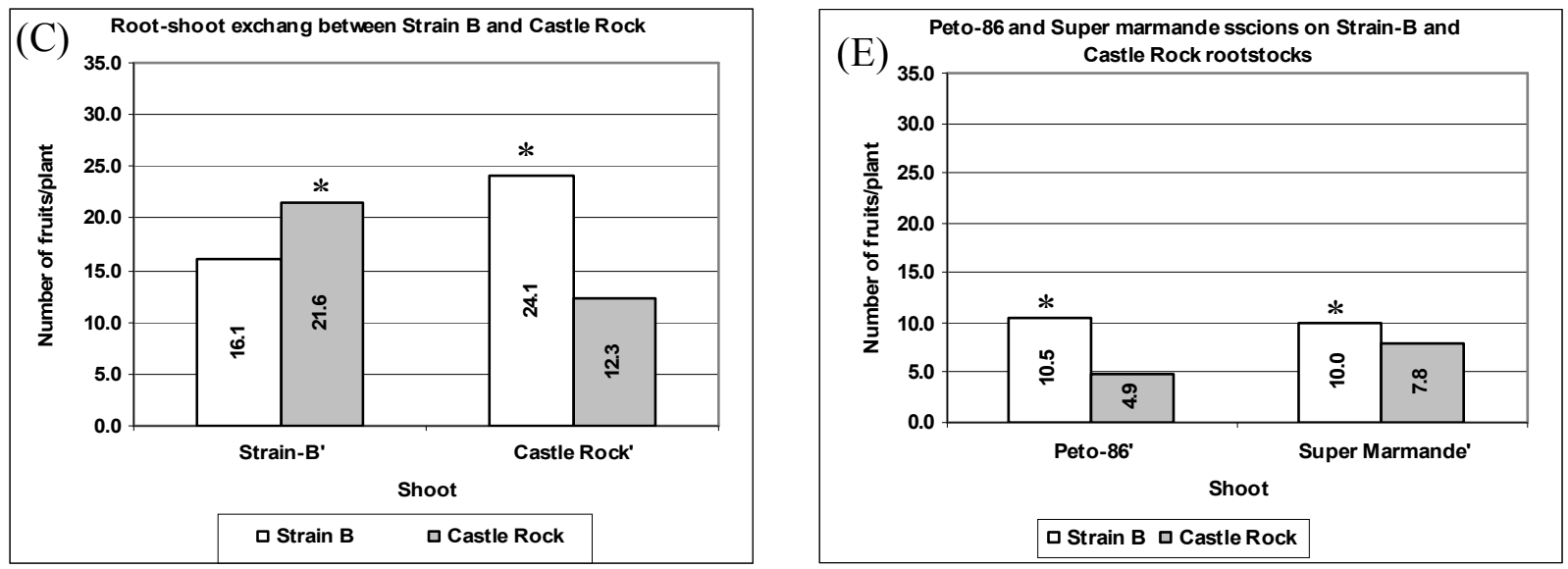

$\mathrm{LSD}_{0.05}:$ Root $=0.7$ Shoot $=1.0$ RootXShoot $=1.3$

$\underline{\text { Cross grafts } 2013}$
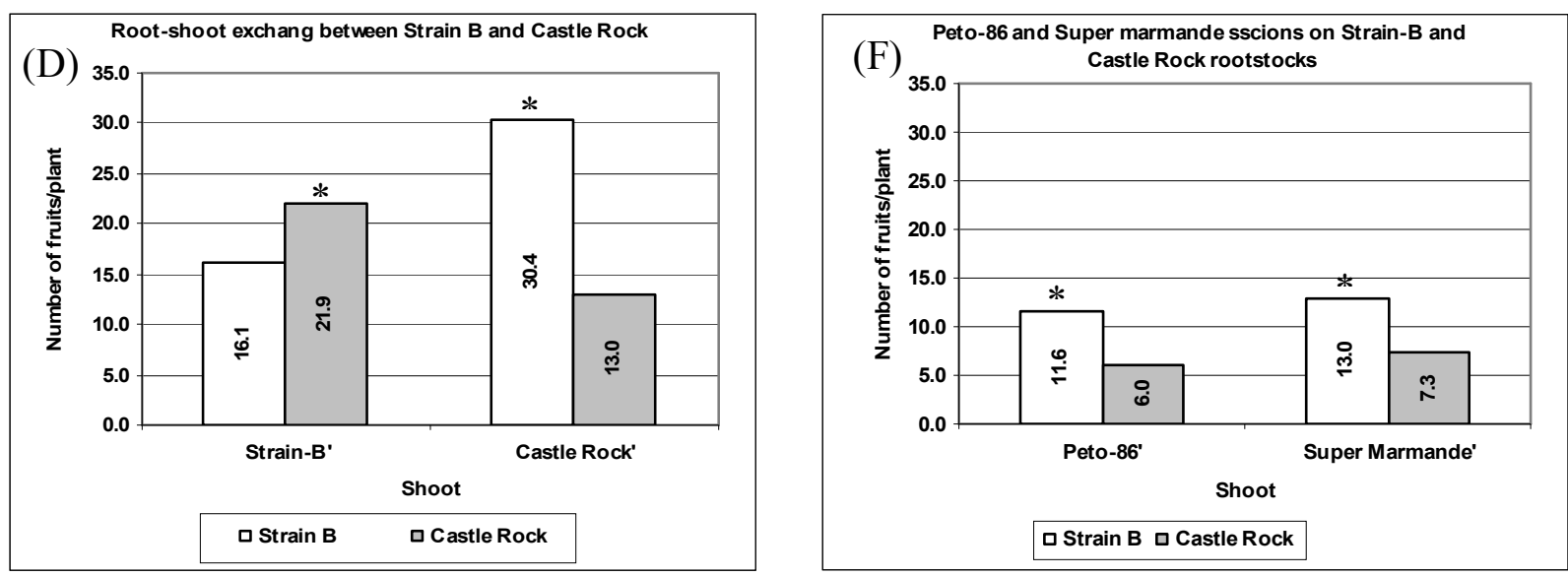

$\mathrm{LSD}_{0.05}:$ Root $=0.5$ Shoot $=0.7$ RootXShoot $=1.0$

Fig., (3): Average number of fruits/plant produced in the summer season in 2012 and 2013 for self-grafts versus intact plants of tomato cultivars 'Strain-B' and 'Castle Rock' (A and B), cross-grafts resulted from root/shoot exchange between cv 'Strain-B' (SB) and cv 'Castle Rock' and cross-grafts of cv 'Peto-86' and 'Super Marmande' scions on rootstocks of cv 'Strain-B' and 'Castle Rock' . Stars denote significant difference between each two adjacent columns. 
Self graft 2012

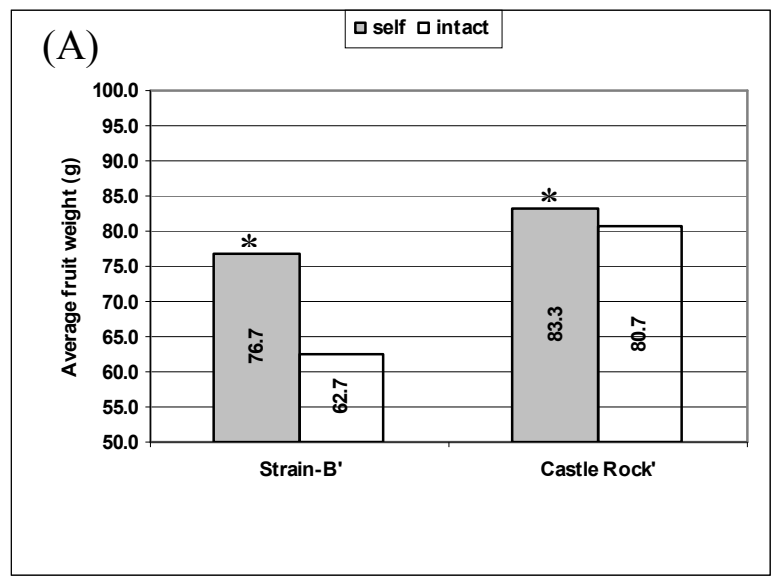

$\mathrm{LSD}_{0.05}:$ Cvs $=2.8$, Self-grafts $=2.8$ CvsXSelf-grafts $=4.0$
Self graft 2013

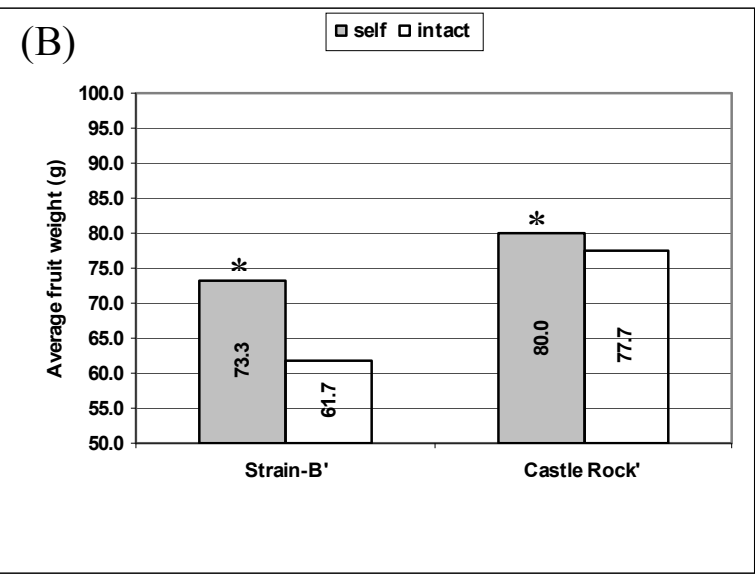

$\mathrm{LSD}_{0.05}:$ Cvs $=3.4$ Self-grafts $=3.4$ CvsXSelf-grafts $=4.8$

\section{Cross grafts 2012}
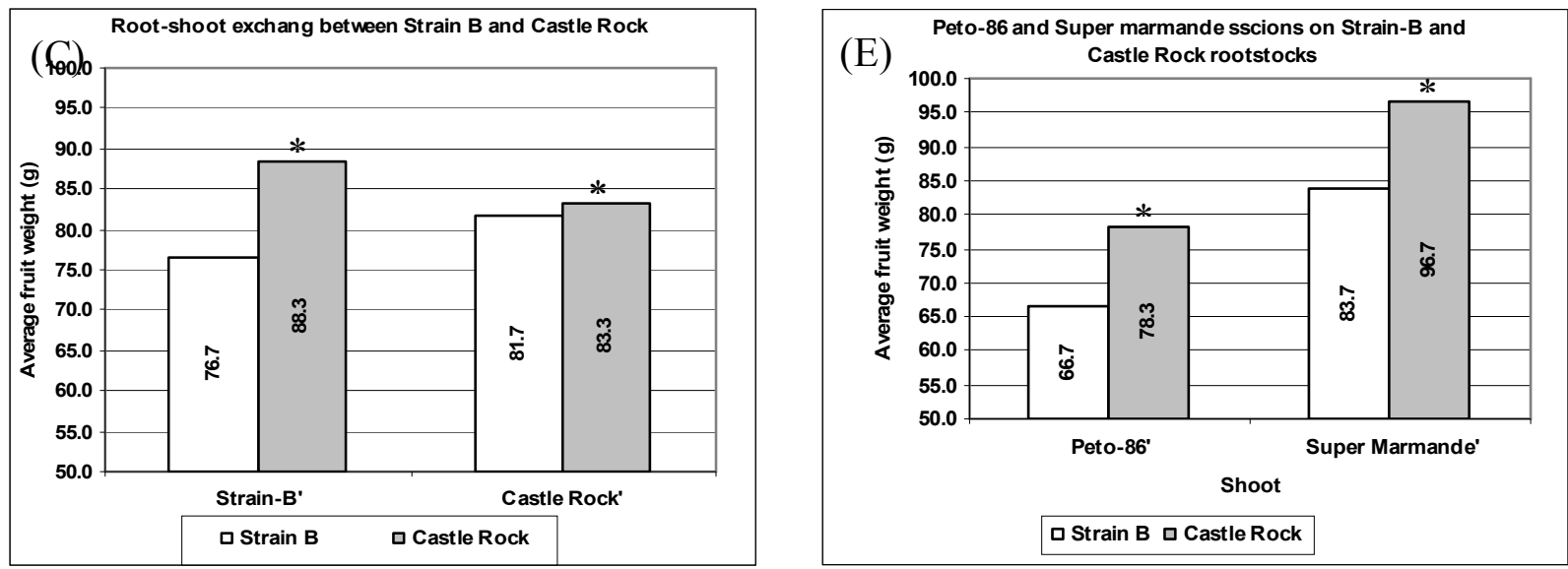

$\mathrm{LSD}_{0.05}:$ Root $=1.5$ Shoot $=2.1$ RootXShoot $=2.9$

Cross grafts 2013
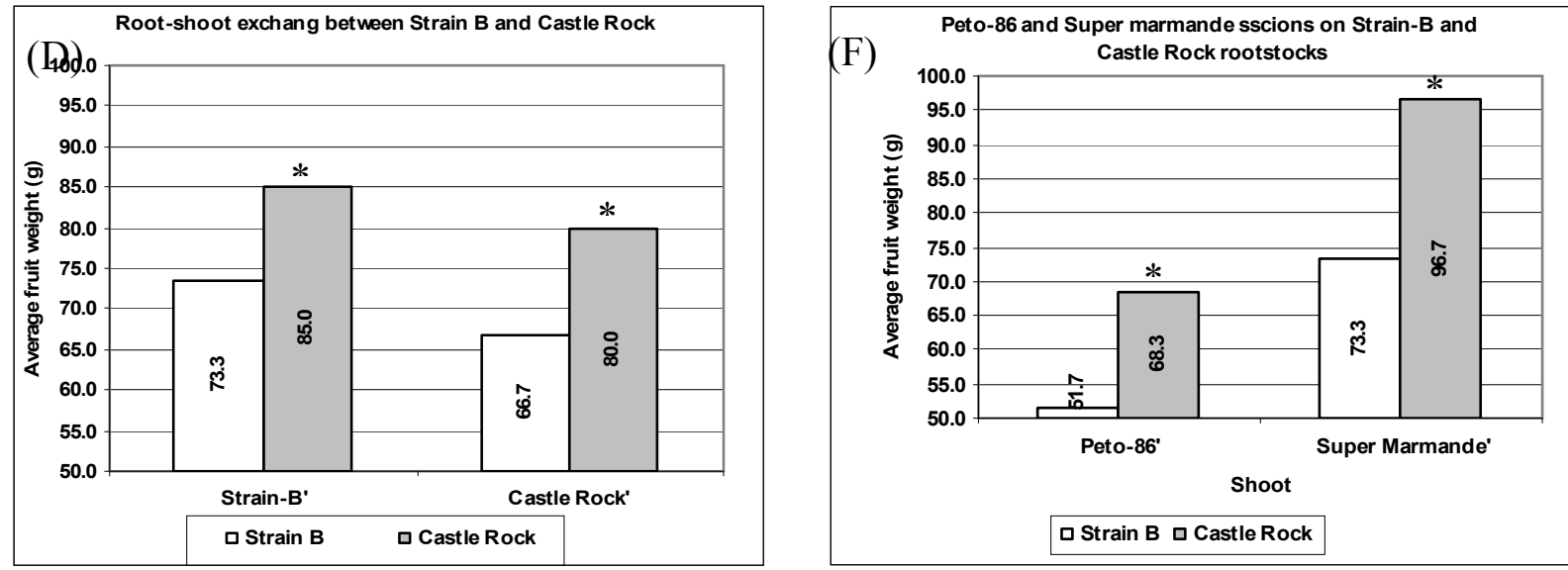

$\mathrm{LSD}_{0.05}:$ Root $=2.0$ Shoot $=2.9$ RootXShoot $=4.1$

Fig., (4): Average weight of tomato fruit produced in the summer season in 2012 and 2013 for self-grafts versus intact plants of cultivars 'Strain-B' and 'Castle Rock' (A and B), cross-grafts resulted from root/shoot exchange between cv 'Strain-B' (SB) and cv 'Castle Rock' and cross-grafts of cv 'Peto-86' and 'Super Marmande' scions on rootstocks of cv 'Strain-B' and 'Castle Rock' . Stars denote significant difference between each two adjacent columns. 
Self graft 2012

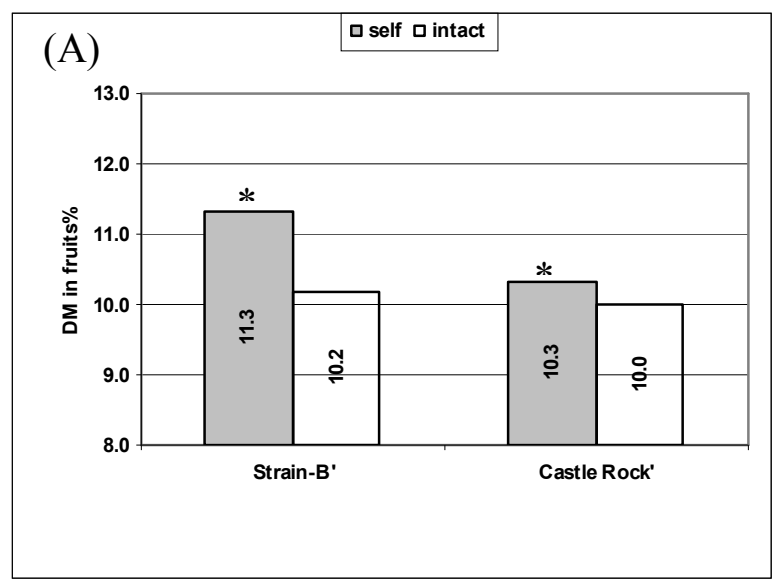

$\mathrm{LSD}_{0.05}:$ Cvs $=0.4$, Self-grafts $=0.4$ CvsXSelf-grafts $=0.6$
Self graft 2013

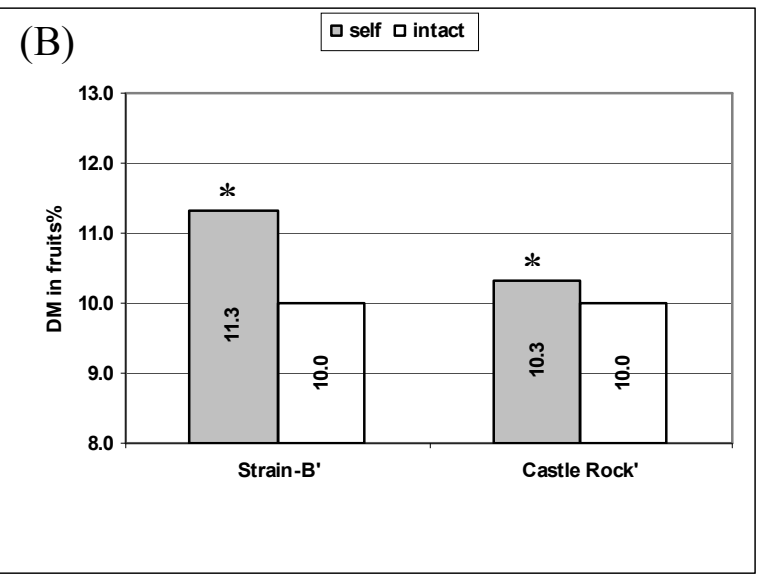

$\mathrm{LSD}_{0.05}:$ Cvs $=0.5$ Self-grafts $=0.5$ CvsXSelf-grafts $=0.7$

\section{Cross grafts 2012}
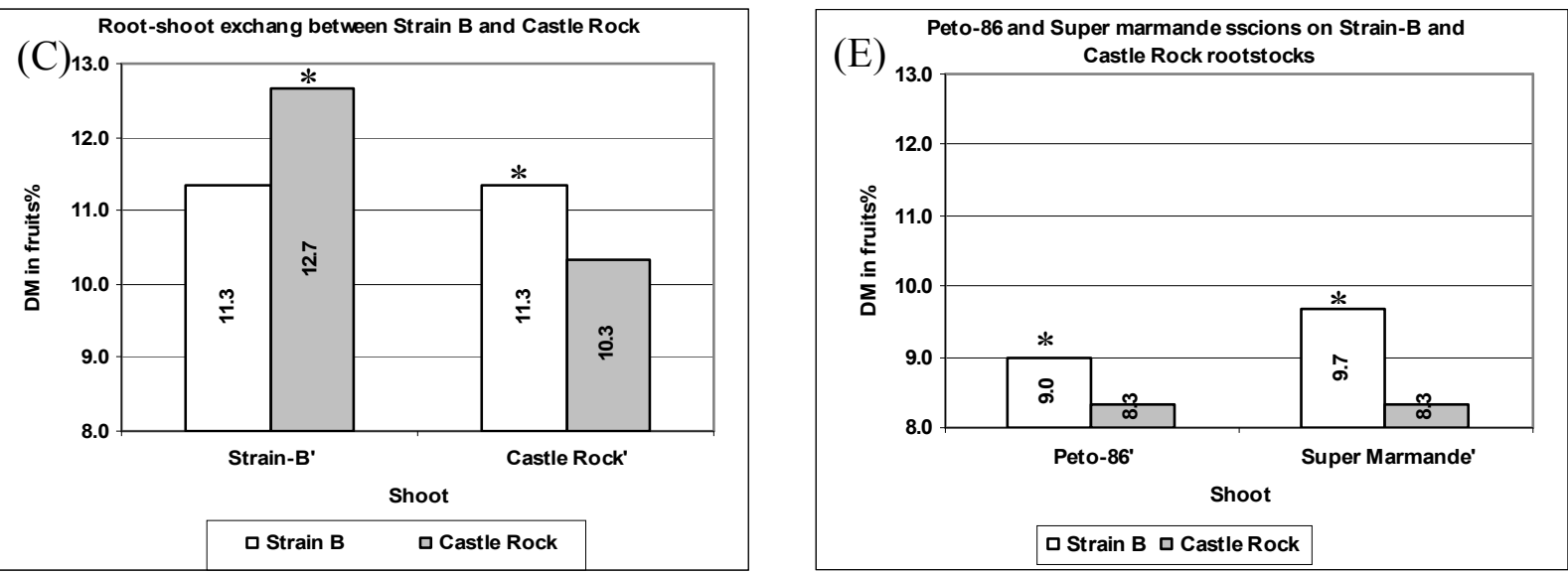

$\mathrm{LSD}_{0.05}:$ Root $=0.4$ Shoot $=0.6$ RootXShoot $=0.8$

Cross grafts 2013
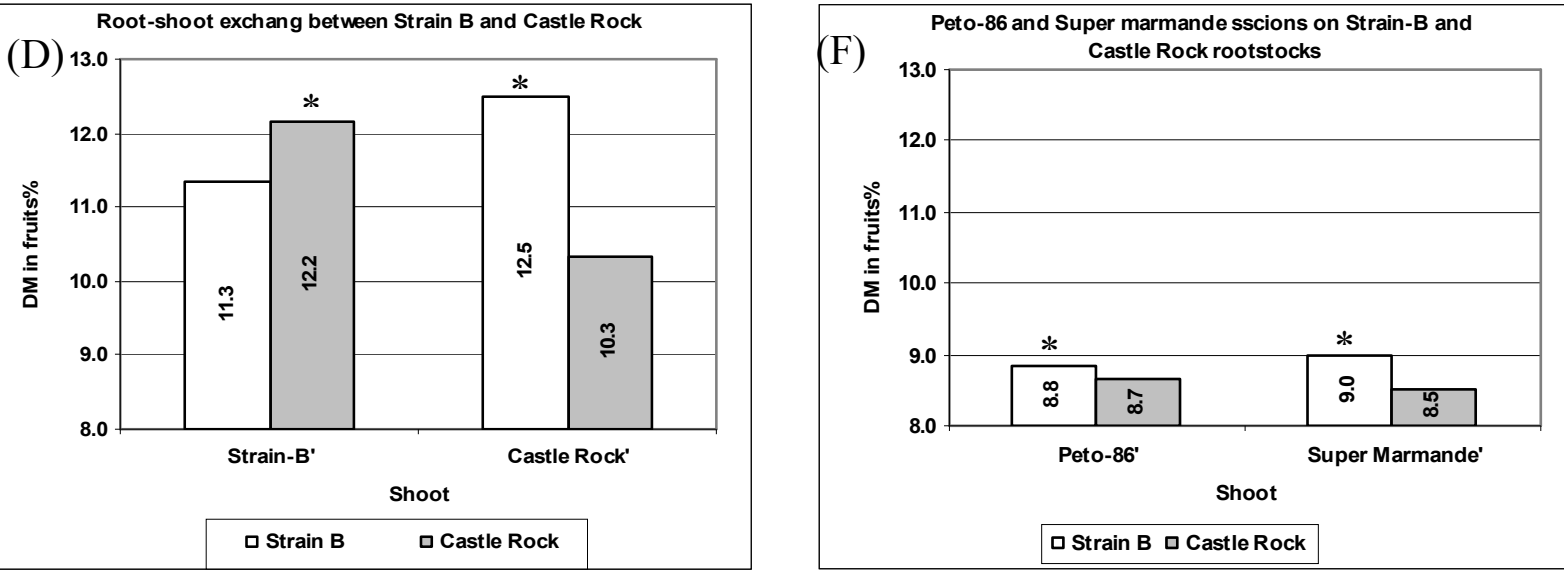

$\mathrm{LSD}_{0.05}:$ Root $=0.4$ Shoot $=0.6$ RootXShoot $=0.8$

Fig., (5): Average dry matter content in tomato fruits produced in the summer season in 2012 and 2013 for self-grafts versus intact plants of cultivars 'Strain-B' and 'Castle Rock' (A and B), cross-grafts resulted from root/shoot exchange between cv 'Strain-B' (SB) and cv 'Castle Rock' and cross-grafts of cv 'Peto-86' and 'Super Marmande' scions on rootstocks of cv 'Strain-B' and 'Castle Rock' . Stars denote significant difference between each two adjacent columns. 


\section{References:}

Aloni, B, R. Cohen, L. Karni, H. Aktas, and M. Edelstein. 2010. Hormonal signaling in rootstock-scion interactions. Scientia Horticulturae 127:119-126.

Colla, G., Rouphael, Y., Leonardi, C., Bie, Z., 2010. Role of grafting in vegetable crops grown under saline conditions. Sci. Hortic. 127, 147-155.

Devlin, R.M. and F.H. Witham 1983. Plant physiology. Forth edition. Willard Grant Press, Boston.

Flores, F.B., Sanchez-Bel, P., Estan, M.T., Martinez-Rodriguez, M.M., Moyano, E., Morales, B., CRmpos, J.F., Gracia-Abellan, J.O., Egea, M.I., FernandezeGarcia, N., Romojaro, F., Bolarin, M.C., 2010. The effectiveness of grafting to improve tomato fruit quality. Sci. Hortic. 125, 211217.

Gomez, K.A. and A.A. Gomez. 1984. Statistical Procedures for Agricultural Research. 2nd Ed. Wily, New York.

Harada T. 2010. Grafting and RNA transport via phloem tissue in horticultural plants. Scientia Horticulturae 125:545-550.

Hassan, A. A. 2008. Tomato (in Arabic). 1st ed., Published by Arab House for Publishing and Distribution, CRiro, Egypt.

He, Y., Zhu, Z.J., Yang, J., Ni, X.L., Zhu, B., 2009. Grafting increases the salt tolerance of tomato by improvement of photosynthesis and enhancement of antioxidant enzymes activity. Environ. Exp. Bot. 66, 270-278.

Lee, J.-M., Kubota, C., Tsao, S.J., Bie, Z., HoyosEchevarria, P., Morra, L., Oda, M., 2010. Current status of vegetable grafting: Diffusion, grafting techniques, automation. Sci. Hortic. 127, 93-105.

Lee, J.M., Oda, M., 2003. Grafting of herbaceous vegetable and ornamental crops. Hortic. Rev. 28, 61-124.

Liu, Z.L., Zhu, Y.L., Wei, G.P., Yang, L.F., Zhang, G.W., Hu, C.M., 2007. Metabolism of ascorbic acid and glutathione in leaves of grafted eggplant seedlings under $\mathrm{NaCl}$ stress. Acta Bot. Boreal-Occident Sin. 27, 17951800.

Mohamed, F. M., M. F. Abd ElKader and G. I. Shalaby. 2002. New Potential Hybrid 'Assiut-15' for Production of Tomato under Adverse High Temperature Conditions. Proc. The Third Sci . Conf. Agric. Sci. p. 385-392, Oct. 20-22, Assiut Univ.

Rivard, C.L., Louws, F.J., 2008. Grafting to manage soilborne diseases in heirloom tomato production. Hortscience 43, 2104-2111.

Rivero, R.M., J.M. Ruiz, and L. Romero. 2003. CRn grafting in tomato plants strengthen resistance to thermal stress? J. Sci. Food Agric. 83:1315-1319.

Savvas D., G. Colla, Y. Rouphael and D. Schwarz. 2010. Amelioration of heavy metal and nutrient stress in fruit vegetables by grafting. Scientia Horticulturae 127 (2010) 156-161.

Schwarza, D., Y. Rouphael, G. Colla, J. H. Venema. 2010. Grafting as a tool to improve tolerance of vegetables to abiotic stresses: Thermal stress, water stress and organic pollutants. Scientia Horticulturae 127:162-171. 
إنتاجية الطماطم المطعومة المزروعة في العروة الصيفية تحت الظروف البيئية للوادي الجديد

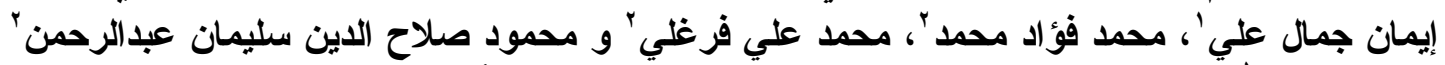

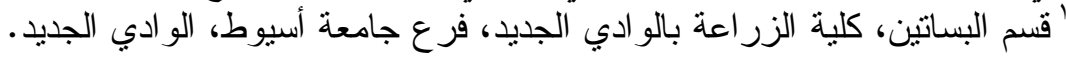
كَّم الخضر ، كلية الزر اعة، جامعة أسيوط، أسيوط.

أجريت هذه الدر اسة في مزرعة محطة البحوث الزر اعية بمركز الخارجة بالو ادي الجديـــ

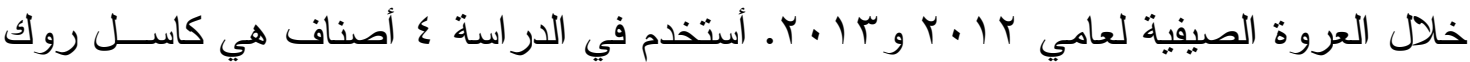
وسترين بي وسوبر مارمند وبيتو -1 . وذلك بغرض التعرف علي مسـدي إمكانيــة إســتخدام التطعيم في تحسين تحمل الحر ارة المرتقعة. وقد شملت التجربة . ب معاملة منهـــا r I معاملـــة تطعيم هجيني و ء معاملات تطعيم ذاتي إضافة إلي ء معاملات نباتات غير مطعومة (كنترول). وقد أثنارت النتائج إلي أنه تحت ظروف هذه الدر اسة قد حدث موت للنباتات الغير مطعومة من السوبر مارمند و البيتو -17. كما أن الطعوم علي أصول جذرية منها (التطعيم الذاتي) قد ماتــت أيضاً. و أما فيما يتعلق بالـــ • 1 معامالت المتبقية فقد كان تفوق الطعوم الذاتية علــي النباتــات الغير مطعومة معنوياً خاصة في التبكير في الحصاد و المحصول الكلي للثـــار ـ أمـــا الطعــوم الهجينة فقد كان تقوقها كبير آ متخطياً النباتات المطعومة ذاتياً و الغيـر مطعومــة. ومسـن هـــهـ الدر اسة فإنه يوصي بإستخدام التطعيم الهجيني كاسل روك/سترين بي أو سترين بي/كاسل روك لإنتاج الطماطم تحت ظروف الإجهاد البيئي في العروة الصيفية في الوادي الجديد. ولقــد قـدر

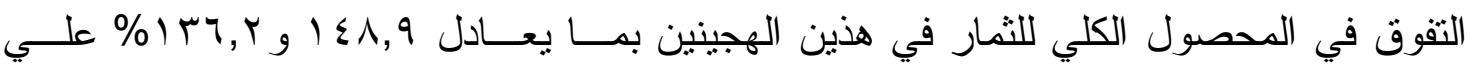
التو الي مقارنة بنباتاتهما الغير مطعومة. 